\title{
Application of Eco-Friendly Natural Dye on Cotton Obtained from the Flower of Opuntia ficus-indica Using Combination of Mordants
}

\author{
M. Kumaresan \\ Department of Chemistry, Arasu Engineering College, Kumbakonam, Tamil Nadu, India \\ $\dagger$ Corresponding author: M. Kumaresan; mkumsrenu@gmail.com
}

Nat. Env. \& Poll. Tech.

Website: www.neptjournal.com

Received: 26-03-2020

Revised: $00-00-00$

Accepted: $27-05-2020$

Key Words:

Cotton, Fastness

Mordant

Natural dye

Opuntia ficus-indica

\begin{abstract}
The fastness properties of the flower of Opuntia ficus-indica dyed cotton fabric have been studied using different combinations (1:3, $1: 1$ and $3: 1)$ of various mordants, such as myrobolan-nickel sulphate, myrobolan-aluminium sulphate, myrobolan-potassium dichromate, myrobolan-ferrous sulphate and myrobolan-stannous chloride. The wash, rub, light and perspiration fastness of the dyed samples have been evaluated. It is found that the flower of Opuntia ficus-indica dye can be successfully used for the dyeing of cotton to obtain a wide range of colours by using various combinations of mordants.
\end{abstract}

\section{INTRODUCTION}

Environmental pollution due to the discharge of dyeing industry effluents is the matter of major concern nowadays. For many years, people have been using all types of natural substances, derived mainly from plants and animals. The use of natural dyes for textile dyeing purposes decreased to a large extent after the discovery of synthetic dyes in 1856. Synthetic dyestuffs produce hazardous by-products (Gulrajani et al. 1992), some of which possess carcinogenic intermediates, and hence a ban has been imposed by Germany and some other European countries on the use of benzidine dyes in textile garments exported into their countries (Anderson 1971 \& Kumaresan et al. 2010). Hence, due to the current eco-consciousness, the attention of researchers has been shifted to the use of natural dyes for dyeing textile materials (Kumaresan et al. 2012, Kumaresan et al. 2015). Dyes derived from natural sources have emerged as an important alternative to synthetic dyes.

\section{MATERIALS AND METHODS}

In the present work, the flower of Opuntia ficus-indica (Fig. 1) growing in all warm and damp parts of India, have been used. Opuntia ficus-indica (prickly pear) is a species of cactus that has long been a domesticated crop plant grown in agricultural economies throughout arid and semiarid parts of the world. Opuntia is grown primarily as a fruit crop, and also for the vegetable nopales and other uses. The dye was used to dye cotton at optimized dyeing conditions, using a combination of mordants and to evaluate the resultant colour fastness of the dyed samples to washing, rubbing, perspiration and light.

Bleached plain weave cotton fabric, obtained from Gandhigram Rural University, Dindigal, was used for the study. AR grade ferrous sulphate, aluminium sulphate, nickel sulphate, potassium dichromate, stannous chloride, and commercial grade acetic acid, common salt and sodium carbonate were used. A natural mordant myrobolan (Terminalia chebula) powder (Kumaresan 2016) was also used for the study. The ethanol extract of the flower of Opuntia ficus-indica was used to get pale brown colour for dyeing fabrics. Depending upon the mordant used, the colour obtained on textiles may give different shades.

A known quantity of flowers of Opuntia Ficus-Indica was dried, powdered and soaked in warm water overnight. The flower of Opuntia ficus-indica extract was obtained by boiling it in the same water. The dye extract was allowed to cool, filtered and used for dyeing. The dyeing was carried out at optimized conditions namely dye extraction time 60 $\mathrm{min}$, material to liquor ratio 1:20, and dyeing time $50 \mathrm{~min}$.

The mordant combinations viz., myrobolan-nickel sulphate, myrobolan-aluminium sulphate, myrobolanpotassium dichromate, myrobolan-ferrous sulphate, and myrobolan-stannous chloride were used in the ratio of 1:3, 1:1 and 3:1. The total amount of two mordants used in each 


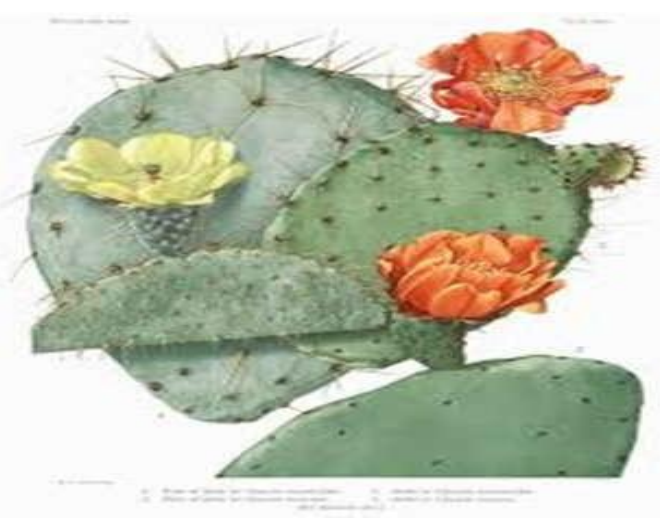

Fig. 1: Floweres of Opuntia ficus-indica.

combination was $5 \%$ on the weight of the fabric i.e., $5 \mathrm{~g}$ of the mordant/100 $\mathrm{g}$ of the fabric. Each of the five mordant combinations in three different ratios mentioned above was used with all the three mordanting methods namely pre mordanting, simultaneous mordanting and post mordanting for dyeing (Kumaresan 2019). After dyeing, the solution was allowed to cool, removed from the dye bath, rinsed under running water to remove excess dye and shade dried.

For optimizing the extraction method, the ethanol extraction of dye liquor was carried out under varying conditions, such as time of extraction, temperature of extraction bath and material-to-liquor ratio (Kundal et al. 2016, Sharada Devi et al. 2002). In each case, the optical density or absorbance value at a particular maximum absorbance wavelength $(\lambda 420 \mathrm{~nm})$ for the ethanol extract of plant parts were estimated by using Hitachi-U-2000 UVVIS absorbance spectrometer.

Colour fastness to the washing of the dyed fabric samples was determined as per IS: 764-1984 method using a Sasmira launder-O-meter following IS-3 wash fastness method (Samanta et al. 2003, Bains et al. 2003). The wash fastness rating was assessed using greyscale as per ISO-05-A02 (loss of shade depth) and ISO-105-AO3 (extent of staining) and the same was cross-checked by measuring the loss of depth of colour and staining using Macbeth 2020 plus computer-aided colour measurement system attached with relevant software.

Colour fastness to rubbing (dry and wet) was assessed (Senthilkumar et al. 2002) as per IS: 766-1984 method using a manually operated crock meter and greyscale as per ISO105-AO3 (extent of staining). Colour fastness to exposure to light was determined as per IS: $2454-1984$ method. The sample was exposed to UV light in a Shirley MBTF Microsal fade-O-meter (having 500 Watt Philips mercury bulb tungsten filament lamp simulating daylight) along with the eight blue wool standards (BS1006: BOI: 1978).

Colour fastness to perspiration, assessed according to IS: 971-1983 composite specimen, was prepared by placing the test specimen between two adjacent pieces of fabrics of silk and cotton and stitched all among four sides. The sample was soaked in the test solution (acidic/alkaline) separately with MLR 1:50 for 30 minutes at room temperature. The sample was then placed between two glass plates of perspirometer under the load of $4.5 \mathrm{~kg}$. The apparatus was kept in the oven for four hours at $37 \pm 2{ }^{\circ} \mathrm{C}$. At the end of this period, the specimen was removed and dried in air at a temperature not exceeding $60^{\circ} \mathrm{C}$. The test samples were graded for change in colour and staining using grey scales.

Table 1: Fastness grades of the flower of Opuntia ficus-indica dye, dyed on cotton at optimum dyeing conditions (wavelength $440 \mathrm{~nm}$, dye extraction time 60min, material to liquor ratio 1:20, dyeing time $50 \mathrm{~min}$ ) using Mb-NS mordant combination.

\begin{tabular}{|c|c|c|c|c|c|c|c|c|c|c|c|}
\hline \multirow[t]{4}{*}{ Mordanting Method } & \multirow{4}{*}{$\begin{array}{l}\text { Mordant } \\
\text { Properties }\end{array}$} & \multirow{4}{*}{$\begin{array}{l}\text { Light } \\
\text { Fastness } \\
\text { Grade }\end{array}$} & \multirow{2}{*}{\multicolumn{2}{|c|}{$\begin{array}{l}\text { Wash Fastness } \\
\text { Grades }\end{array}$}} & \multirow{2}{*}{\multicolumn{3}{|c|}{$\begin{array}{l}\text { Rub Fastness } \\
\text { Grades }\end{array}$}} & \multicolumn{4}{|c|}{ Perspiration Fastness } \\
\hline & & & & & & & & \multicolumn{2}{|c|}{ Acidic } & \multicolumn{2}{|c|}{ Alkaline } \\
\hline & & & \multirow[t]{2}{*}{$\mathrm{CC}$} & \multirow[t]{2}{*}{$\mathrm{CS}$} & \multicolumn{2}{|l|}{ Dry } & \multirow{2}{*}{$\begin{array}{l}\text { Wet } \\
\mathrm{CC}\end{array}$} & \multirow[t]{2}{*}{$\mathrm{CS}$} & \multirow[t]{2}{*}{$\mathrm{CC}$} & \multirow{2}{*}{$\mathrm{CS}$} & \multirow[t]{2}{*}{$\mathrm{CC}$} \\
\hline & & & & & $\mathrm{CC}$ & $\mathrm{CS}$ & & & & & \\
\hline \multirow[t]{3}{*}{ Pre Mordanting } & $1: 3$ & $3-4$ & 4 & 5 & 5 & 5 & 5 & 4 & 5 & 4 & 5 \\
\hline & $1: 1$ & $3-4$ & $4-5$ & 5 & 5 & $4-5$ & 5 & 4 & 5 & $4-5$ & 5 \\
\hline & $3: 1$ & $3-4$ & 4 & 5 & $4-5$ & 5 & 5 & 5 & 5 & 5 & 5 \\
\hline \multirow[t]{3}{*}{ Simultaneous Mordanting } & $1: 3$ & $3-4$ & $4-5$ & 5 & 5 & 5 & 5 & 5 & 5 & 5 & 5 \\
\hline & $1: 1$ & $3-4$ & 4 & 5 & 5 & 5 & 5 & 5 & 5 & 5 & 5 \\
\hline & $3: 1$ & $3-4$ & $4-5$ & 5 & 5 & $4-5$ & 5 & 4 & 5 & 5 & 5 \\
\hline \multirow[t]{3}{*}{ Post Mordanting } & $1: 3$ & $3-4$ & 4 & 4 & 5 & 5 & 5 & 4 & 5 & 5 & $4-5$ \\
\hline & $1: 1$ & $3-4$ & $4-5$ & 5 & $4-5$ & 5 & 5 & 4 & 5 & $4-5$ & $4-5$ \\
\hline & $3: 1$ & $3-4$ & 4 & 5 & 5 & 5 & 5 & 4 & 5 & 5 & 5 \\
\hline
\end{tabular}

Mb-NS = Myrobolan-Nickel sulphate, $\mathrm{CC}=$ Colour change, $\mathrm{CS}=$ Colour staining 


\section{RESULTS AND DISCUSSION}

\section{Mordant Combination: Myrobolan-Nickel Sulphate}

The evaluation of colour fastness to light, washing, rubbing and perspiration of flower of Opuntia ficus-indica dyed cotton samples treated with myrobolan-nickel sulphate combination in the aqueous medium is presented in Table 1. All the treated samples subjected to light showed fairly good (3-4) light fastness for all ratio mordant combinations. The washing fastness grades ranged between 4 and 5-4 for all the treated samples and there was no colour staining. The colour change to dry and wet rubbing for all the treated samples was excellent (5).

\section{Mordant Combination: Myrobolan-Aluminium Sulphate}

The evaluation of colour fastness to light, washing, rubbing and perspiration of flower of Opuntia ficus-indica dyed cotton samples treated with myrobolan-aluminium sulphate combination in the aqueous medium is presented in Table 2. All the treated samples subjected to light showed fairly good (3-4) light fastness for all ratios of mordant combinations. The treated samples for pre mordanting showed fair (3 to 2-3) washing fastness grades, but they ranged from excellent to good (4-5 to 4) for all the treated samples for simultaneous and post mordanting. There was no colour staining. The colour change to dry and wet rubbing for all the treated samples was excellent (5). There was no colour staining ranged from no staining to negligible staining (5 to 4-5) in dry rubbing.

\section{Mordant Combination: Myrobolan-Potassium Dichromate}

The evaluation of colour fastness to light, washing, rubbing and perspiration of flower of Opuntia ficus-indica dyed cotton samples treated with Myrobolan-potassium dichromate combination in an aqueous medium is presented in Table 3 . The treated samples subjected to light showed fairly good (3-4) light fastness for all ratio mordant combinations. The washing fastness grades showed fairly good (3-4) for all the treated samples. The colour change to dry and wet rubbing for all the treated samples was excellent (5).

\section{Mordant Combination: Myrobolan-Ferrous Sulphate}

The evaluation of colour fastness to light, washing, rubbing and perspiration of flower of Opuntia Ficus-Indica dyed cotton samples treated with myrobolan: ferrous sulphate combination in an aqueous medium is presented in Table 4. The treated samples subjected to light showed fairly good (4-3-4) light fastness for all ratios of mordant combinations. The washing fastness grades ranged from excellent to good (5-4) for all the treated samples. The colour change to dry and wet rubbing for all the treated samples was excellent (5).

\section{Mordant Combination: Myrobolan-Stannous Chloride}

The evaluation of colour fastness to light, washing, rubbing and perspiration of flower of Opuntia ficus-indica dyed cotton samples treated with myrobolan-stannous chloride combination in an aqueous medium is presented in Table 5. The treated samples subjected to light showed fairly good (4 to 3-4) light fastness for all the ratios of mordant

Table 2: Fastness grades of the flower of Opuntia ficus-indica dye, dyed on cotton at optimum dyeing conditions (wavelength $440 \mathrm{~nm}$, dye extraction time $60 \mathrm{~min}$, material to liquor ratio 1:20, dyeing time $50 \mathrm{~min}$ ) using Mb-AS mordant combination.

\begin{tabular}{|c|c|c|c|c|c|c|c|c|c|c|c|}
\hline \multirow[t]{4}{*}{ Mordanting Method } & \multirow{4}{*}{$\begin{array}{l}\text { Mordant } \\
\text { Properties }\end{array}$} & \multirow{4}{*}{$\begin{array}{l}\text { Light } \\
\text { Fastness } \\
\text { Grade }\end{array}$} & \multirow{2}{*}{\multicolumn{2}{|c|}{$\begin{array}{l}\text { Wash Fastness } \\
\text { Grades }\end{array}$}} & \multirow{2}{*}{\multicolumn{3}{|c|}{$\begin{array}{l}\text { Rub Fastness } \\
\text { Grades }\end{array}$}} & \multicolumn{4}{|c|}{ Perspiration Fastness } \\
\hline & & & & & & & & Aci & & Alke & \\
\hline & & & \multirow{2}{*}{$\mathrm{CC}$} & \multirow{2}{*}{$\mathrm{CS}$} & Dry & & Wet & \multirow{2}{*}{$\mathrm{CS}$} & \multirow{2}{*}{$\mathrm{CC}$} & \multirow{2}{*}{$\mathrm{CS}$} & \multirow{2}{*}{$\mathrm{CC}$} \\
\hline & & & & & $\mathrm{CC}$ & CS & $\mathrm{CC}$ & & & & \\
\hline \multirow[t]{3}{*}{ Pre Mordanting } & $1: 3$ & $3-4$ & 4 & 5 & 4 & 5 & $4-5$ & 4 & 5 & 4 & 5 \\
\hline & $1: 1$ & 3 & 5 & 5 & 4 & $4-5$ & $4-5$ & 4 & 5 & $4-5$ & 5 \\
\hline & $3: 1$ & 4 & 4 & 5 & 4 & 5 & 5 & 5 & 5 & 5 & $4-5$ \\
\hline \multirow{3}{*}{$\begin{array}{l}\text { Simultaneous Mor- } \\
\text { danting }\end{array}$} & $1: 3$ & 4 & 5 & $4-5$ & 5 & 5 & 5 & 5 & 5 & $4-5$ & $4-5$ \\
\hline & $1: 1$ & 4 & 5 & $4-5$ & 5 & 5 & 5 & 5 & 5 & 5 & 5 \\
\hline & $3: 1$ & 4 & $4-5$ & 5 & 5 & $4-5$ & 5 & 4 & 5 & 5 & 5 \\
\hline \multirow[t]{3}{*}{ Post Mordanting } & $1: 3$ & 4 & 4 & 4 & 5 & 5 & 5 & 4 & 4 & $4-5$ & 4 \\
\hline & $1: 1$ & $3-4$ & 4 & 4 & $4-5$ & 5 & 4 & 4 & 4 & $4-5$ & 4 \\
\hline & $3: 1$ & $3-4$ & 4 & 4 & 5 & 5 & 4 & 4 & $4-5$ & 5 & 5 \\
\hline
\end{tabular}

$\mathrm{Mb}-\mathrm{AS}=$ Myrobolan-Aluminium sulphate, $\mathrm{CC}=$ Colour change, $\mathrm{CS}=$ Colour staining 
Table 3: Fastness grades of the flower of Opuntia ficus-indica dye, dyed on cotton at optimum dyeing conditions (wavelength 440 nm. dye extraction time $60 \mathrm{~min}$, material to liquor ratio 1:20, dyeing time $50 \mathrm{~min}$.) using Mb-PD mordant combination.

\begin{tabular}{|c|c|c|c|c|c|c|c|c|c|c|c|}
\hline \multirow[t]{4}{*}{ Mordanting Method } & \multirow{4}{*}{$\begin{array}{l}\text { Mordant } \\
\text { Properties }\end{array}$} & \multirow{4}{*}{$\begin{array}{l}\text { Light } \\
\text { Fastness } \\
\text { Grade }\end{array}$} & \multirow{2}{*}{\multicolumn{2}{|c|}{$\begin{array}{l}\text { Wash Fastness } \\
\text { Grades }\end{array}$}} & \multirow{2}{*}{\multicolumn{3}{|c|}{$\begin{array}{l}\text { Rub Fastness } \\
\text { Grades }\end{array}$}} & \multicolumn{4}{|c|}{ Perspiration Fastness } \\
\hline & & & & & & & & \multicolumn{2}{|c|}{ Acidic } & \multicolumn{2}{|c|}{ Alkaline } \\
\hline & & & \multirow[t]{2}{*}{$\mathrm{CC}$} & \multirow[t]{2}{*}{$\mathrm{CS}$} & \multicolumn{2}{|c|}{ Dry } & Wet & \multirow[t]{2}{*}{$\mathrm{CS}$} & \multirow[t]{2}{*}{$\mathrm{CC}$} & \multirow[t]{2}{*}{$\mathrm{CS}$} & \multirow[t]{2}{*}{$\mathrm{CC}$} \\
\hline & & & & & $\mathrm{CC}$ & $\mathrm{CS}$ & $\mathrm{CC}$ & & & & \\
\hline \multirow[t]{3}{*}{ Pre Mordanting } & $1: 3$ & $3-4$ & 4 & 4 & 3 & 4 & 3 & 4 & 4 & 4 & 4 \\
\hline & $1: 1$ & $3-4$ & $4-5$ & 4 & 3 & $3-4$ & 3 & 4 & 4 & 4 & 4 \\
\hline & $3: 1$ & $3-4$ & 4 & 4 & 3 & 4 & 3 & 3 & $3-4$ & $3-4$ & 3 \\
\hline \multirow{3}{*}{$\begin{array}{l}\text { Simultaneous } \\
\text { Mordanting }\end{array}$} & $1: 3$ & $3-4$ & $3-4$ & 4 & $3-4$ & 4 & 4 & 3 & $3-4$ & $3-4$ & $3-4$ \\
\hline & $1: 1$ & $3-4$ & $3-4$ & 4 & $3-4$ & 4 & 4 & 3 & $3-4$ & $3-4$ & 4 \\
\hline & $3: 1$ & $3-4$ & $3-4$ & $3-4$ & $3-4$ & 4 & $3-4$ & 3 & 3 & 3 & 4 \\
\hline \multirow[t]{3}{*}{ Post Mordanting } & $1: 3$ & $3-4$ & 4 & 4 & 4 & 4 & 4 & 4 & 4 & 3 & $3-4$ \\
\hline & $1: 1$ & $3-4$ & $4-5$ & 3 & 3 & 3 & 3 & 4 & 4 & 3 & 3 \\
\hline & $3: 1$ & $3-4$ & 4 & 3 & 3 & 3 & 3 & 4 & 4 & $3-4$ & $3-4$ \\
\hline
\end{tabular}

$\mathrm{Mb}-\mathrm{PD}=$ Myrobolan-Potassium dichromate, $\mathrm{CC}=$ Colour change, $\mathrm{CS}=$ Colour staining

Table 4: Fastness grades of the flower of Opuntia ficus-indica dye, dyed on cotton at optimum dyeing conditions (wavelength 440 nm. dye extraction time 60min, material to liquor ratio 1:20, dyeing time $50 \mathrm{~min}$.) using Mb:FS mordant combination.

\begin{tabular}{|c|c|c|c|c|c|c|c|c|c|c|c|}
\hline \multirow{4}{*}{$\begin{array}{l}\text { Mordanting } \\
\text { Method }\end{array}$} & \multirow{4}{*}{$\begin{array}{l}\text { Mordant } \\
\text { Properties }\end{array}$} & \multirow{4}{*}{$\begin{array}{l}\text { Light } \\
\text { Fastness } \\
\text { Grade }\end{array}$} & \multirow{2}{*}{\multicolumn{2}{|c|}{$\begin{array}{l}\text { Wash Fastness } \\
\text { Grades }\end{array}$}} & \multirow{2}{*}{\multicolumn{3}{|c|}{$\begin{array}{l}\text { Rub Fastness } \\
\text { Grades }\end{array}$}} & \multicolumn{4}{|c|}{ Perspiration Fastness } \\
\hline & & & & & & & & \multicolumn{2}{|c|}{ Acidic } & \multicolumn{2}{|c|}{ Alkaline } \\
\hline & & & \multirow[t]{2}{*}{$\mathrm{CC}$} & \multirow[t]{2}{*}{$\mathrm{CS}$} & \multicolumn{2}{|c|}{ Dry } & Wet & \multirow[t]{2}{*}{$\mathrm{CS}$} & \multirow[t]{2}{*}{$\mathrm{CC}$} & \multirow[t]{2}{*}{$\mathrm{CS}$} & \multirow[t]{2}{*}{$\mathrm{CC}$} \\
\hline & & & & & $\mathrm{CC}$ & $\mathrm{CS}$ & $\mathrm{CC}$ & & & & \\
\hline \multirow[t]{3}{*}{ Pre Mordanting } & $1: 3$ & $3-4$ & 4 & 4 & $4-5$ & 5 & 5 & 4 & $4-5$ & 4 & $4-5$ \\
\hline & $1: 1$ & $3-4$ & $4-5$ & 4 & $4-5$ & $4-5$ & 5 & 4 & $4-5$ & $4-5$ & $4-5$ \\
\hline & $3: 1$ & $3-4$ & 4 & 4 & $4-5$ & $4-5$ & 5 & 4 & 5 & 5 & $4-5$ \\
\hline \multirow{3}{*}{$\begin{array}{l}\text { Simultaneous } \\
\text { Mordanting }\end{array}$} & $1: 3$ & $3-4$ & $3-4$ & 4 & 5 & 5 & 5 & 5 & 5 & 5 & 5 \\
\hline & $1: 1$ & $3-4$ & $3-4$ & 4 & 5 & 5 & 5 & 5 & 5 & 5 & 5 \\
\hline & $3: 1$ & $3-4$ & $3-4$ & $3-4$ & 5 & 5 & 5 & 5 & 5 & 5 & 5 \\
\hline \multirow[t]{3}{*}{ Post Mordanting } & $1: 3$ & $3-4$ & 4 & 4 & 5 & $4-5$ & $4-5$ & 4 & 4 & 5 & $4-5$ \\
\hline & $1: 1$ & $3-4$ & $4-5$ & 3 & $4-5$ & $4-5$ & $4-5$ & 4 & $4-5$ & $4-5$ & $4-5$ \\
\hline & $3: 1$ & $3-4$ & 4 & 3 & $4-5$ & $4-5$ & $4-5$ & 4 & 4 & 4 & 5 \\
\hline
\end{tabular}

Mb-FS: Myrobolan-Ferrous sulphate, $\mathrm{CC}=$ Colour change, $\mathrm{CS}=$ Colour staining

Table 5: Fastness grades of the flower of Opuntia ficus-indica dye, dyed on cotton at optimum dyeing conditions (wavelength $440 \mathrm{~nm}$, dye extraction time $60 \mathrm{~min}$, material to liquor ratio 1:20, dyeing time $50 \mathrm{~min}$ ) using Mb-SC mordant combination.

\begin{tabular}{|c|c|c|c|c|c|c|c|c|c|c|c|}
\hline \multirow{4}{*}{$\begin{array}{l}\text { Mordanting } \\
\text { Method }\end{array}$} & \multirow{4}{*}{$\begin{array}{l}\text { Mordant } \\
\text { Properties }\end{array}$} & \multirow{4}{*}{$\begin{array}{l}\text { Light } \\
\text { Fastness } \\
\text { Grade }\end{array}$} & \multirow{2}{*}{\multicolumn{2}{|c|}{$\begin{array}{l}\text { Wash Fastness } \\
\text { Grades }\end{array}$}} & \multirow{2}{*}{\multicolumn{3}{|c|}{$\begin{array}{l}\text { Rub Fastness } \\
\text { Grades }\end{array}$}} & \multicolumn{4}{|c|}{ Perspiration Fastness } \\
\hline & & & & & & & & \multicolumn{2}{|c|}{ Acidic } & \multicolumn{2}{|c|}{ Alkaline } \\
\hline & & & \multirow[t]{2}{*}{$\mathrm{CC}$} & \multirow[t]{2}{*}{$\mathrm{CS}$} & Dry & & Wet & CS & $\mathrm{CC}$ & $\mathrm{CS}$ & $\mathrm{CC}$ \\
\hline & & & & & $\mathrm{CC}$ & $\mathrm{CS}$ & $\mathrm{CC}$ & & & & \\
\hline \multirow[t]{3}{*}{ Pre Mordanting } & $1: 3$ & $3-4$ & 4 & 4 & $3-4$ & 4 & $3-4$ & 4 & $3-4$ & $3-4$ & 4 \\
\hline & $1: 1$ & $3-4$ & $4-5$ & 4 & $3-4$ & 4 & 4 & 4 & 4 & 4 & 4 \\
\hline & $3: 1$ & $3-4$ & 4 & 4 & 4 & $3-4$ & 4 & 4 & $3-4$ & $3-4$ & 3 \\
\hline \multirow{3}{*}{$\begin{array}{l}\text { Simultaneous } \\
\text { Mordanting }\end{array}$} & $1: 3$ & $3-4$ & $4-5$ & 4 & 4 & 4 & 4 & 4 & $3-4$ & $3-4$ & $3-4$ \\
\hline & $1: 1$ & $3-4$ & $4-5$ & 4 & 4 & 4 & 4 & 4 & $3-4$ & $3-4$ & 4 \\
\hline & $3: 1$ & $3-4$ & 4 & $4-5$ & $3-4$ & $3-4$ & $3-4$ & 4 & 3 & 4 & 4 \\
\hline \multirow[t]{3}{*}{ Post Mordanting } & $1: 3$ & $3-4$ & $4-5$ & 4 & 4 & 4 & 4 & 4 & 4 & 4 & 4 \\
\hline & $1: 1$ & $3-4$ & $4-5$ & 4 & $3-4$ & $3-4$ & $3-4$ & 4 & 4 & 4 & 4 \\
\hline & $3: 1$ & $3-4$ & 4 & 4 & $3-4$ & $3-4$ & $3-4$ & 4 & 4 & 4 & 4 \\
\hline
\end{tabular}

$\mathrm{Mb}-\mathrm{SC}=$ Myrobolan-Stannous chloride, $\mathrm{CC}=$ Colour change, $\mathrm{CS}=$ Colour staining 
combinations. The washing fastness grades ranged be- tween excellent to good (4-5 to 3-4) for all the treated samples and there was no colour staining. The colour change to dry and wet rubbing for all the treated samples was excellent (5). The colour staining ranged from negligible to slight staining (4-5) in both dry and wet rubbing.

\section{CONCLUSION}

It was found from the study that flower of Opuntia ficus-indica dye can be successfully used for dyeing cotton to obtain a wide range of soft, pastel and light colours by using a combination of mordants. With regards to colour fastness, test samples exhibited excellent fastness to washing (except for pre- mordanting using myrobolan-potassium dichromate combination); excellent fastness to rubbing (except for pre-mordanting using myrobolan-potassium dichromate combination); and good to excellent fastness to perspiration in both acidic and alkaline media and fairly good fastness to light.

\section{ACKNOWLEDGEMENT}

The authors are thankful to Dr P. N. Palanisamy, Department of Chemistry, Kongu Engineering College for his support and help for the completion of this work.

\section{REFERENCES}

Anderson, B. 1971. Creative spinning, weaving and plant dyeing. Angus and Robinson, Singapore, pp. 24-28.
Bains, S., Singh, O.P., Goraya, G. and Kang, M. 2003. Dyeing of cotton with Goldendrop (Onosma echioides) dye. Journal of the Textile Association, pp. 183-186.

Gulrajani, M. L. and Gupta, Deepti 1992. Natural Dye and their Application to Textiles (Department of TextileTechnology, IIT, Delhi), 25.

Kumaresan, M 2015. Comparison of properties of eco-friendly natural dyed cotton fabric. International Journal of Der Pharma Chemica, 7(4): 257-260.

Kumaresan, M. 2016. Application of eco-friendly natural dye obtained from Spathodea campanulata on silk using combination of mordants. Management of Environmental Quality, 27(1): 15-21.

Kumaresan, M. 2019. Dyeing of cotton fabric with eco-friendly natural dye obtained from Opuntia ficus-indica using single mordants. Journal of Applied Science and Computations, V(XII): 2290-2294.

Kumaresan, M., Palanisamy, P.N. and Kumar, P.E. 2012. Application of eco-friendly natural dye on cotton using combination of mordants. Indian Journal of Fibre \& Textile Research, 37: 194-198.

Kumaresan, M., Palanisamy, P.N. and Kumar, P.E. 2010. Application of eco-friendly natural dyes on cotton obtained from the stem of Achras sapota using a combination of mordants. Nature Environment and Pollution Technology, 9(3): 547-552.

Kundal, J.S.V.S., Singh, S.V. and Purohit, M.C. 2016. Extraction of natural dye from Ficus cunia and dyeing of polyester cotton and wool fabric using different mordants, with evaluation of colour fastness properties. Natural Products Chemistry \& Research, 4(3): 1-6.

Samanta, A. K. and Singhee, D. 2003. Application of single and mixture of selected natural dyes on cotton fabric - A scientific approach. Colourage, 50(10): 29-42.

Senthilkumar, P., Umashankar, P. and Sujatha, B. 2002. Ultrasonic dyeing of cotton fabrics with neem leaves. The Indian Textile Journal, 58(3): 15-18.

Sharada Devi, A. Sumanthy, B. S. and Katyayini, V.K.L.T. 2002. Eclipta prostate- A weed rich in coloured pigments for silk. Man Made Textiles in India, pp. 181-189. 